\section{Annals of Spiru Haret University \\ Economic Series \\ Since 2000 \\ ISSN: 2393-1795 ISSN-L:2068-6900}

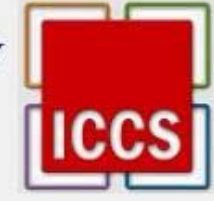

Issue $2 / 2016$

\title{
THE IMPACT OF MANAGEMENT COMMUNICATION ON THE DECISIONS TO INCREASE THE PERFORMANCE OF AN ORGANIZATION
}

\author{
Cezarina Adina TOFAN \\ "Spiru Haret" University, Ion Ghica Street, no. 13, Bucharest, 030045, \\ Romania, Tel.: +40214551000, Fax: +40213143900, \\ Email: adina.tofan@spiruharet.ro
}

\section{Abstract}

Many Romanian companies are going through a difficult period, which makes the care of managers to materialize more on obtaining immediate profit and rarely on some less obvious aspects such as communication influence on labour productivity. Often managers do not consider communication as a factor of real importance that may affect the staff's performance.

The way we communicate with those around us in the professional activity, but not only, places a mark on the results. Quality of management communication influences the way how the human resource is used and the organizational performance, in particular. Each individual has a certain style of communication formed by education, skills, beliefs and personal goals. It does not always ensure the effective and efficient communication.

It can be appreciated the necessity for managers to see in subordinates, but also on themselves, the change of attitude towards "science communication" by realizing the positive and negative effects of their own style of communication and by raising awareness of the necessity to acquire some communication skills.

Key words: analysis; impact; managerial communication; decision making.

JEL Classification: M20, M21, M10, M14 


\section{ \\ Annals of Spiru Haret University \\ Economic Series \\ Since 2000}

ISSN: 2393-1795 ISSN-L:2068-6900

\section{Issue 2/2016}

\section{Introduction}

A competent manager should not communicate at random and at will, but according to the methods and styles of communication to support the implementation of the organizational strategy.

The communication styles used by managers generate the communication climate specific to the organization, and on this climate depends their performance and productivity [Cândea \& Cândea, 1996].

The business communication has arisen as a management subject of the necessity to provide the manager the optimum means of interaction to fulfil its roles and functions. The efficient and effective business communication is a factor of competitiveness, a strategic advantage of the organization.

Communication becomes a harmonization instrument in the human resource management, the basic managerial instrument in fulfilling the functions and objectives of the organization.

\section{Literature Review}

In 1920, the first business communication courses at Harvard, Virginia Darden School and Dartmouth Tuck School in the USA were introduced. Gradually, they become compulsory in the education of each American manager, later on they were implemented in Europe as well.

The period after 1970 marked the transition to the performance management in the world, when the manager becomes the entrepreneur, in addition to the resource manager and leader. As a manager and leader, one optimizes the results of an existing business because the market, products, services and technologies already exist; it means one has to make the effective and efficient decisions. Drawing on his skills as good communicator one gets a coordinating information node, a centre of decision and management.

Hence, it appears the necessity for an organization strategy and developing a spirit of the responsibility towards the individual, society and environment.

In this context, Business Communication does not have only the role of transmitting the information messages, training, persuasion and motivation. It becomes a dynamic and independent force that is modelled by the environment in which it operates. The communication system creates the powerful tools for 


\section{An Anals of Spiru Haret University \\ Economic Series \\ Since 2000 \\ ISSN: 2393-1795 ISSN-L:2068-6900}

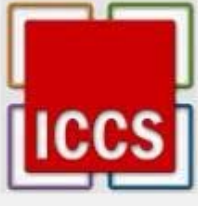

Issue $2 / 2016$

continuous adjustment of the structure and organization processes to the conditions in constant changing. The basic role of managers is to develop and keep alive the communication system designed to support the implementation of the organization's strategy, the "nervous system" of the organization's "body".

Information, knowledge and creativity become the organization's strategic resources. All these are inconceivable outside the effective and efficient communication that becomes a competitiveness instrument of the organization.

\section{Theoretical Background}

Starting from the implications that management communication can have on the labour productivity, both within the organization level and the relations between employees, the influence of the managerial communication styles on the labour productivity growth will be investigated.

In conducting the research it was necessary to define the managerial communication styles.

Grouping of the communication styles into four categories: "blame", "information-routing", "belief" and "problem solving" was chosen because we think that it corresponds most to the communication styles used by managers in practice.

The main characteristics of these communication styles are [Pâinişoară, 2003]:

- The "blame" style, which aims to criticize, to accuse, to find fault and to find a guilty person. The manager adopts an attitude of judge, of assessor. He is one who speaks and does not accept replies or views from the receiver (subordinate). Using this style, the manager will achieve the desired effect, namely the subordinate will change his behaviour on time, and either accepts or recognizes the accusation;

- The "information-routing" style, which aims to give explanations, instructions and decisions. The manager conceives beforehand the message and the subordinate must execute. The message is made clear, concise and focused on the task that the subordinate must meet;

- The "belief" style, which aims to reach an agreement, accept a plan, perform an action, implement a change. The manager dominates the 


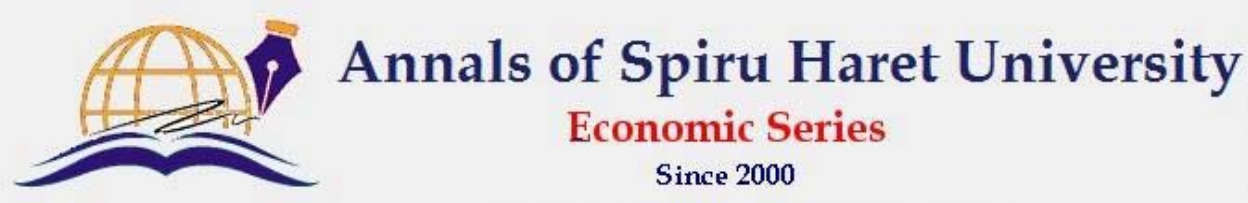

ISSN: 2393-1795 ISSN-L:2068-6900

\section{Issue 2/2016}

communication as he knows the situation and solution. To convince the subordinate, the manager listens actively and offers feedback. If the arguments used by the message sent are rational, the manager can manage to convince the subordinate.

- The "problem solving" style, which aims to solve the problems. Calling the principles of supportive communication and none of the parties does not dominate the communication. The communication is descriptive, based on facts, and each party expresses their views, even if they are contrary.

At the level of the organization the strategies of the individual communication must fit into a unitary communication strategy to ensure the implementation of the organization's strategy, both in action and indirectly through the climate of the generated communication.

Organizations must develop the loyalty of the employees to increase productivity, stability and ability to progress.

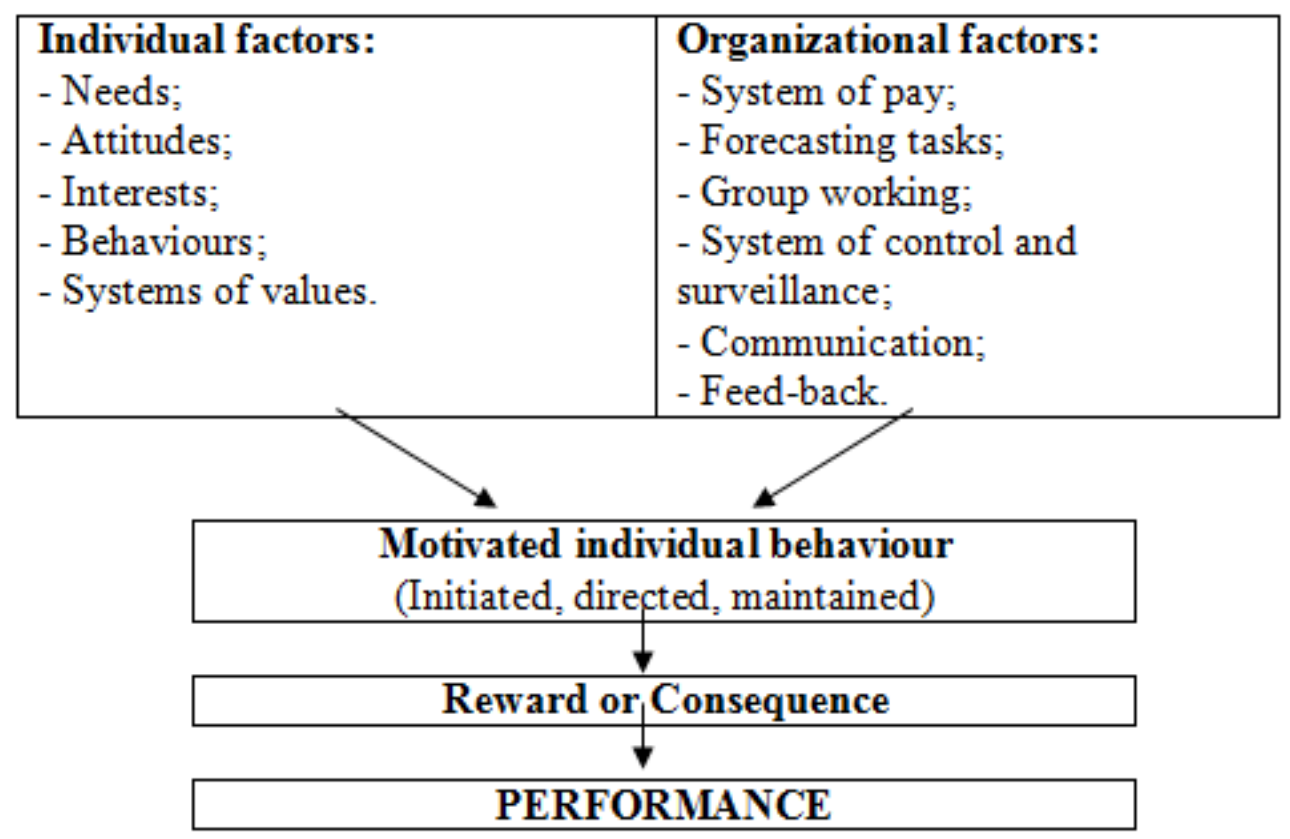

Figure no. 1. General model of motivation oriented towards the managerial success

Source: made of my own 


\section{Annals of Spiru Haret University Economic Series Since 2000}

Characteristics of the individual (Traits, personality)

Rate of absenteeism

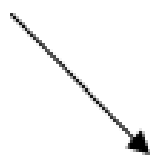

JOB

SATISFACTION

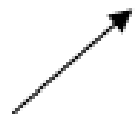

Characteristics of the job (job elements)
ASSESSMENT SYSTEM (positive or negative)

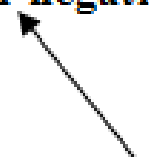

Rate of fluctuation

Figure no. 2. Causal model: satisfaction, absenteeism, fluctuation Source: made of my own

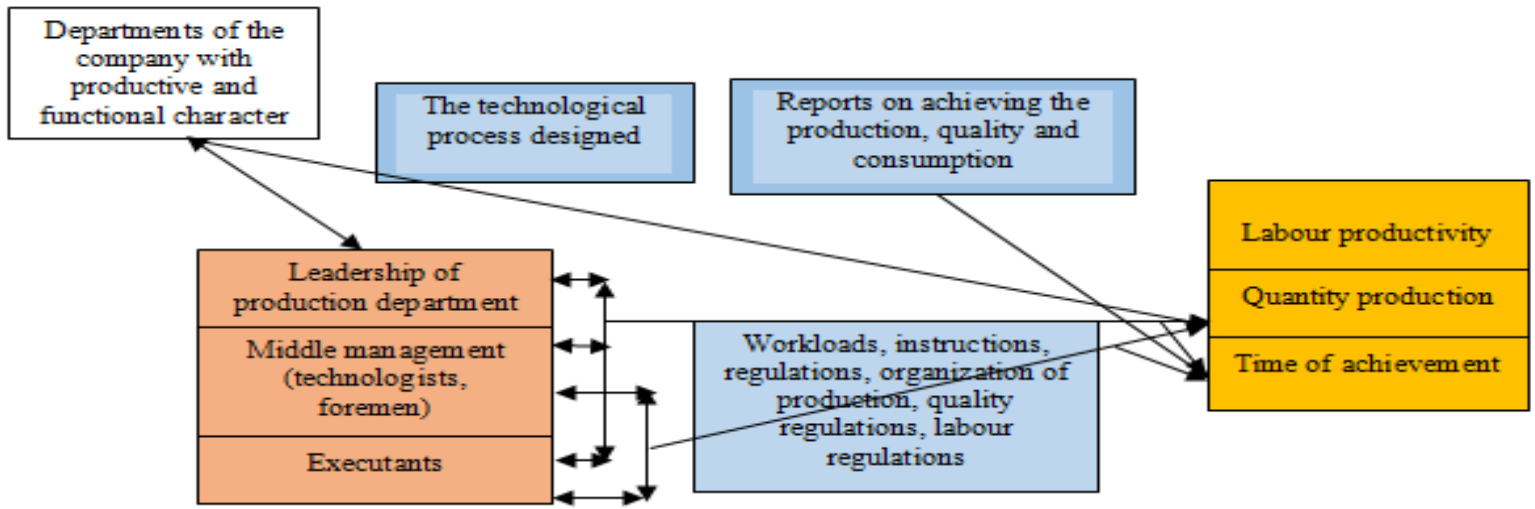

$$
\begin{aligned}
& \text { Reporting on production achieved } \\
& \text { reports of labour, human resources } \\
& \text { issues, complaints on the conduct of } \\
& \text { of the production process }
\end{aligned}
$$

\section{Figure no. 3. Correlation between communication and labour}

\section{productivity}

Source: After processing Lupu L. Voicu M., Impactul comunicării manageriale asupra creşterii productivității muncii în cadrul unei organizații, www.managementmarketing.ro, 

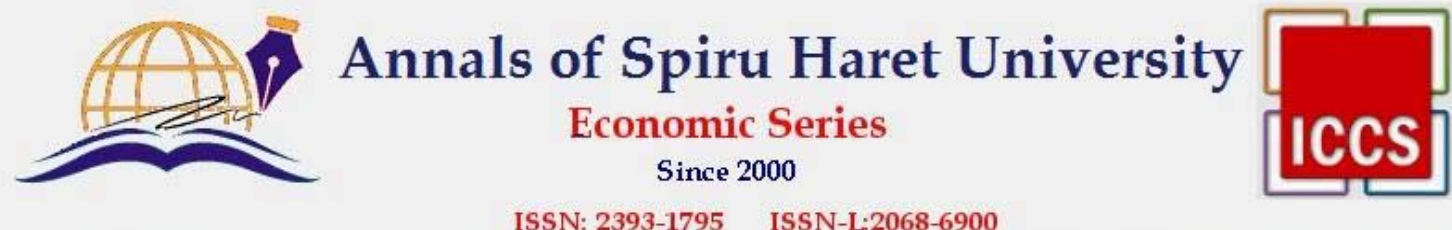

ISSN: 2393-1795 ISSN-L:2068-6900

\section{Issue $2 / 2016$}

Job satisfaction can lead to confidence in the organization, which means that the employee's expectations have been met: desired salary, recognition, good relations with managers and colleagues and the company philosophy and the organizational culture, every dimension contributing to outlining the sense of work satisfaction. Job satisfaction depends both on the individual characteristics and those of the job. Dissatisfaction occurs when the employee's expectations about work are deceived.

Interpersonal communication is in few situations, or not at all, seen as a factor with direct implications in increasing or decreasing the labour productivity in an organization.

Between communication and labour productivity a correlation is realized which can be represented schematically:

Although the effective management communication leads to increasing the labour productivity and to a better motivation of the employees, the vast majority of operational managers do not use this tool, one reason being the lack of communication skills.

To support them, we encourage the managerial communication rules that can increase the managers' efficiency by communicating more effectively.

To ensure achievement of performance of tasks by the subordinates, it is necessary for the managers to consider the following issues:

- Practicing a style of communication by formulating some clear and concise messages that contain all the details necessary for a task;

- Motivating by solid arguments the necessity to achieve the work tasks on time and qualitatively;

- Adapting the message to the subordinate, observing his body language;

- Establishing deadlines for completing tasks; in this way the subordinate will have to manage his time and to perform a quality work;

- Adequate time transmission of information, knowledge and skills to subordinates;

- Analysing individual objectives and concrete tasks of the subordinates to check if they can be reached and if they are motivated; 


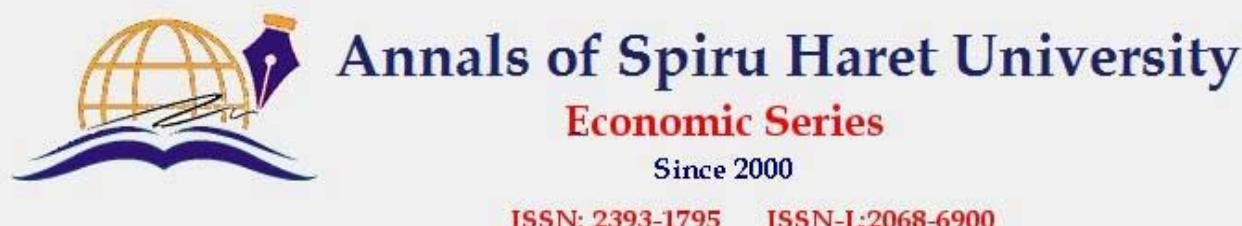

ISSN: 2393-1795 ISSN-L:2068-6900

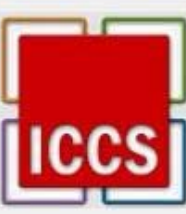

Issue $2 / 2016$

growth;

- Regular information of the subordinates on labour productivity

- Asking questions and encouraging the subordinates to ask questions, because the only way one can find out what problems exist is by asking questions;

- Development of feedback by the manager to ensure that subordinates understand correctly the message;

- Periodic assessment of the performance through regular discussions with their subordinates; it is desirable that the subordinate be praised if the results call for such a thing or to be criticized if there are mistakes and failures. Assessment must be made objectively and in short intervals. Employees will be more motivated and disciplined if they know that their achievements are appreciated.

\section{Paper Content}

The climate of communication within an organization, assessed through a questionnaire, will correspond to a greater or lesser one of two types: Climate Cooperation (emphasis on communication, teamwork, participative management), or a Defensive Climate (emphasis on compliance the rules, individual work, authoritarian management). Any company can be characterized by a certain climate of communication, in other words, style of intra-organizational communication. Equally true, there is the fact that the style of intra-organizational communication can be positive, facilitating the achievement of the individual, group and organizational objectives, or negative, which translate into low employee satisfaction, thus a low efficiency and productivity.

The climate of communication can be translated as the way in which employees of the companies feel or not:

- A degree of freedom in the work they do;

- An interest to hold own opinions from superiors;

- A flexibility degree of the superior in the assessment of problematic situations and decision-making;

- An effective communication with colleagues and superiors, etc. 


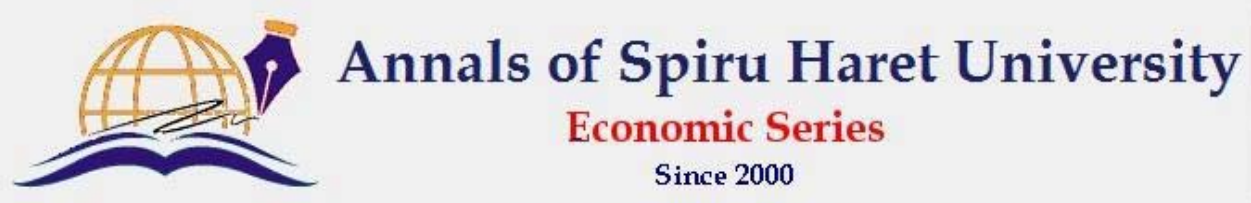

ISSN: 2393-1795 ISSN-L:2068-6900

\section{Issue $2 / 2016$}

Climate Communication questionnaire helps the managers to realize how really it happens or not the exchange / circulation of information in the organizations they lead and thus take the necessary measures to create a climate with positive effects.

The questionnaire contains 15 questions. It was applied to the contractor and to the managers of middle level from several economic entities, mostly with secondary and higher education, female and male alike, with an age range 35-52 years.

In analysing the questionnaire, we used relevant questions to highlight the impact of communication on decisions that may lead to an increase in performance and productivity. So, to the question: Do you think that your chief is interested in your opinions, suggestions?, responses can be plotted as follows:

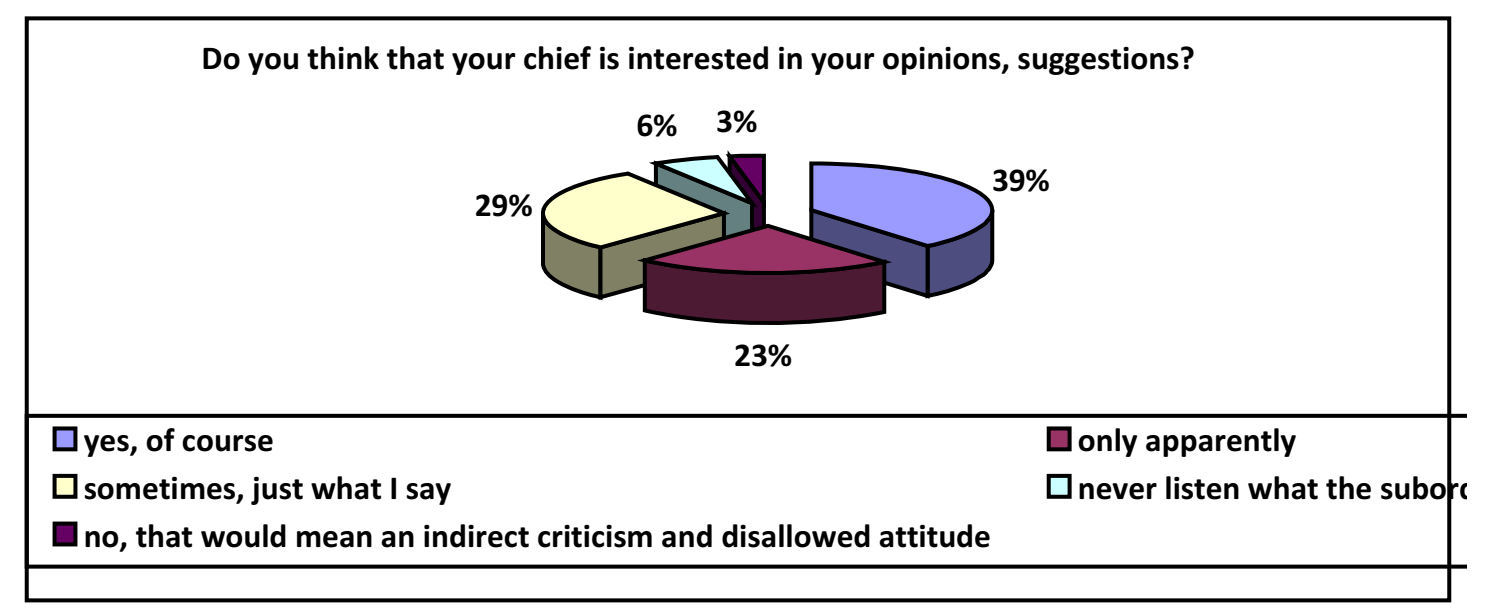

Figure no. 4. Answers to the question Do you think that your chief is interested in your opinions, suggestions?

Source: own calculations

Answers to the statement: Employment relationships with your hierarchical superiors are ... have been highlighted in the chart below: 


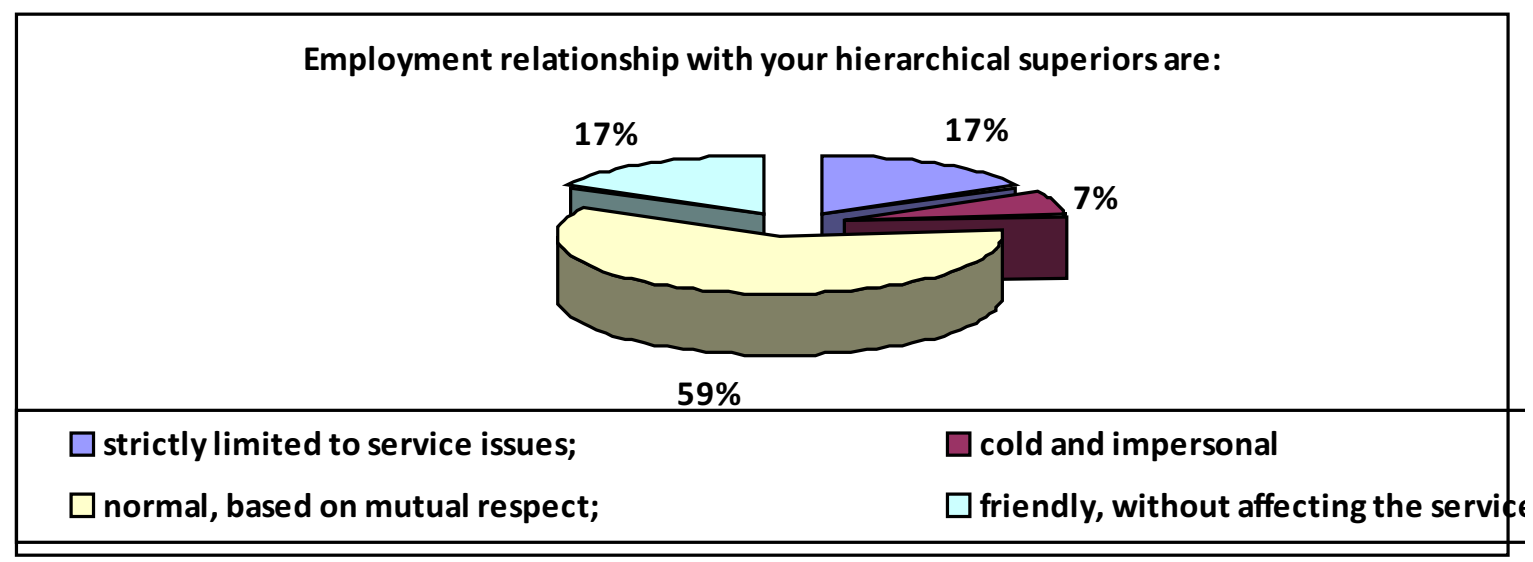

Figure no. 5. Answers to the statement: Employment relationships with your hierarchical superiors are...

Source: own calculations

To the question: Do you think your chief is a person with the following behaviour?

- Nervous;

- Calm;

- Balanced;

- Phlegmatic;

respondents gave the following answers:

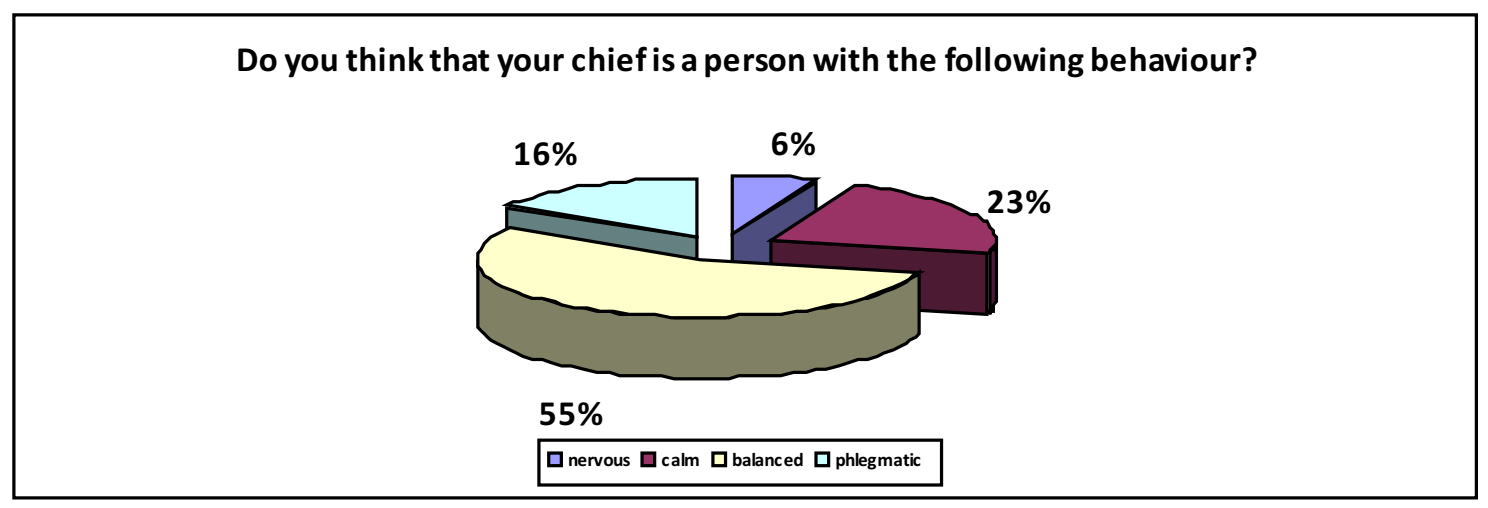

Figure no. 6. Answers to the question: Do you think your chief is a person with the following behaviour?

Source: own calculations 


\section{Annals of Spiru Haret University \\ Economic Series \\ Since 2000}

ISSN: 2393-1795 ISSN-L:2068-6900

\section{Issue 2/2016}

Do you think that your chief is interested in the problems of the team or whether they are

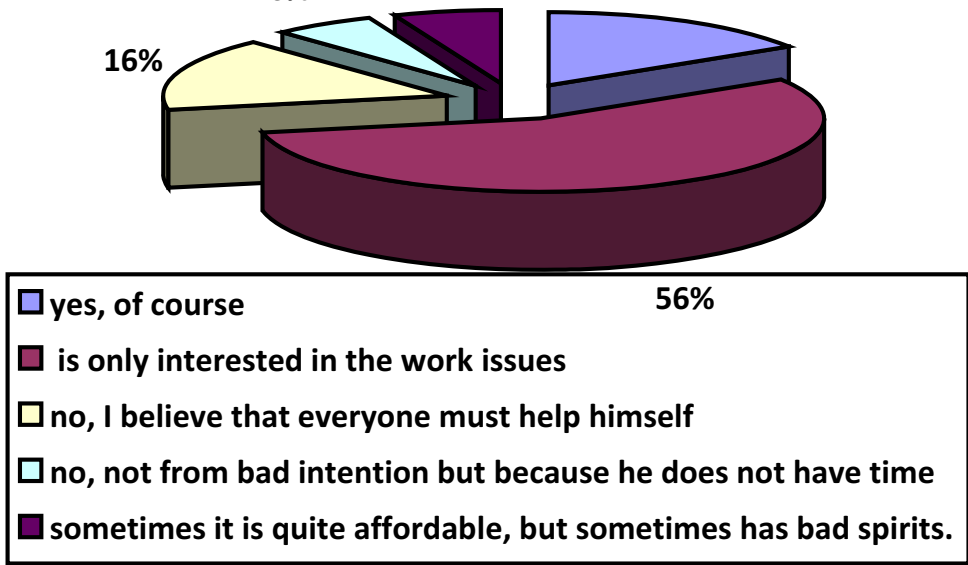

Figure no. 7. Answers to the question: Do you think your chief is interested in the problems of the team or whether they are business or personal?

Source: own calculations

Would you present to your chief a solution that you think is very good, but contrary to his opinion?

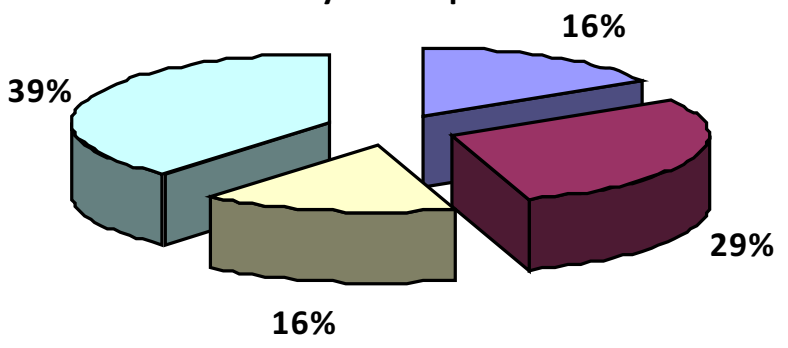

$\square$ yes, could not bear to be contradicted $\square$ in any case, that would cost my i

$\square$ yes, even if I had dissatisfiers $\square$ yes, but with more caution so as

Figure no. 8. Answers to the question: Would you present to your chief a solution you think is very good, but contrary to his opinion?

Source: made of my own 

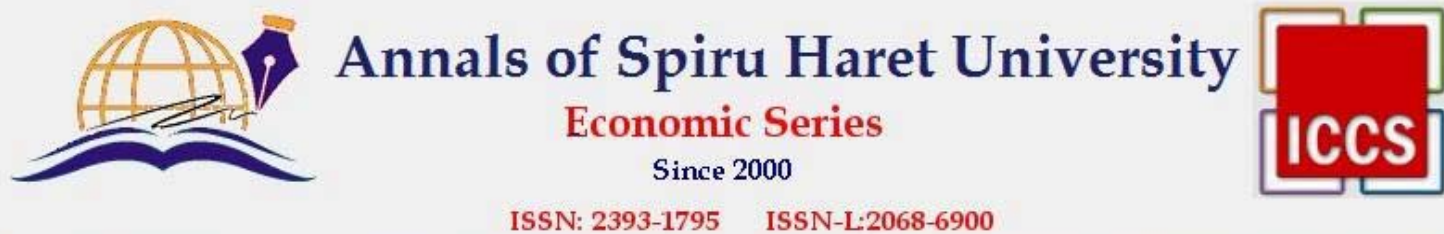

Issue $2 / 2016$

Data were collected in a total of 15 enterprises in the Muscel area, as it was found a very low level of labour productivity and hence the growth paths must be identified.

The sample for the collection of data is a random sample, determined according to the nature of the companies in the area, the number of managers interviewed and performers tested and interviewed in relation to the average proportion of the number of managers-number of performers (20\% managers and $80 \%$ of performers). The activity profile of the companies is mainly textile $60 \%$, mechanical $30 \%$, electrical $10 \%$.

\section{Conclusion}

Communication in business is subject to certain specific rules of ethics, which are found in the organizational culture, policy and organization, and, obviously, in the individual ethics of the managers. Process and products of the management communication are based on concepts, principles, standards and specific guidelines and have specific forms.

Business communication as a form of interpersonal communication has certain peculiarities imposed not only by the purpose, objectives and their role, but also by the organizational framework and organization structure.

Correct interpretation of the message is based on the skills of the manager to analyse and synthesise the information regarding the message thus determining its correct meaning. Once acquired these skills, the interpretation becomes a manager skill without which a communication process cannot be conducted effectively and efficiently.

The message should be adequate to the direction of transmission. In an organization, the internal management communication has specific forms depending on the hierarchical direction in which it is directed. These must comply with certain rules that also depend on the direction of communication that is the relatively hierarchical position between the issuer and recipient. 


\section{Prit \\ Annals of Spiru Haret University \\ Economic Series \\ Since 2000}

ISSN: 2393-1795 ISSN-L:2068-6900

Issue 2/2016

\section{Acknowledgement}

This paper has been developed during the sustainability period of the project called "Horizon 2020 - Doctoral and Postdoctoral Studies: Promoting the National Interest through Excellence, Competitiveness and Responsibility in the Field of Romanian Fundamental and Applied Scientific Research", contract number POSDRU/159/1.5/S/140106. This project is co-financed by the European Social Fund through the Sectoral Operational Programme for Human Resources Development 2007-2013. Investing in people!

\section{References}

1. Cândea, R. M. and Cândea, D., Comunicare managerială (Bucureşti: Editura Expert, 1996).

2. Likert, R., A Method for Coping with Conflict in Problem-Solving Groups, Group \& Organization Management (Wyoming, U.S., December, 1978).

3. Lupu, L. and Voicu, M., Impactul comunicării manageriale asupra creşterii productivității muncii în cadrul unei organizații, www.managementmarketing.ro, 2012.

4. Pâinişoară, I.O., Comunicare eficientă (Iaşi: Editura Polirom, 2003).

5. Prutianu, Şt., Manual de comunicare şi negociere în afaceri (Iaşi: Editura Polirom, 2000).

6. Tofan, C.A., "Metoda arborelui decizional aplicată în adoptarea deciziei de promovare a unei întreprinderi", Annals of Spiru Haret University. Economic Series (Bucureşti: Editura Fundației România de Mâine, vol. 6 (15) issue 3, 2015).

7. Voicu, M. and Drăgoi, R., Comunicare interumană, Aplicații. Studii de caz. Teste (Iaşi: Editura Performantica, 2004).

8. Voicu, M. and Rusu, C., ABC-ul comunicării manageriale (Brăila: Editura Danubius, 1998). 